RESEARCH ARTICLE

\title{
Low-cost culture medium for biomass production of lactic acid bacteria with probiotic potential destined to broilers
}

\author{
Berisvil $A P^{1}$, Astesana $D^{1}{ }^{1}$, Zimmermann $\mathrm{JA}^{1}$, Frizzo $\mathrm{LS}^{1,2}$, Rossler $\mathrm{E}^{1}$, Romero-Scharpen $\mathrm{A}^{1}$, \\ Olivero $\mathrm{CR}^{1}$, Zbrun $\mathrm{MV}^{1,2^{*}}$, Signorini $\mathrm{ML}^{2-4}$, Sequeira $\mathrm{GJ}^{2}$, Drago $\mathrm{SR}^{5}$, Soto $\mathrm{LP}^{1,2}$ \\ ${ }^{1}$ Laboratorio de Análisis de Alimentos, Instituto de Ciencias Veterinarias del Litoral (ICIVET Litoral), \\ Universidad Nacional del Litoral - Consejo Nacional del Investigaciones Científicas y Técnicas (UNL-CONICET), \\ Esperanza, Santa Fe, Argentina. \\ 2 Departmento de Salud Pública, Facultad de Ciencias Veterinarias (FCV), UNL, Argentina. \\ ${ }^{3}$ CONICET, Argentina. \\ ${ }^{4}$ Instituto Nacional de Investigación Agropecuaria - Estación Experimental Agropecuaria Rafaela, Argentina. \\ ${ }^{5}$ Instituto de Tecnología de los Alimentos, Facultad de Ciencias Químicas, UNL, Argentina.
}

* Correspondence: María Virginia Zbrun, ICIVET Litoral (UNL - CONICET), RP Kreder 2805 (CP 3080)

Esperanza, Santa Fe, Argentina. E-mail: virginiazbrun@yahoo.com.ar

Recibido: 16 Abril 2020. Aceptado: 1 Diciembre 2020. Disponible en línea: 24 de Diciembre 2020

Editor: P. Beldomenico

SUMMARY. The aim of this study was to evaluate different low-cost culture media for biomass production of 3 potential probiotic $L$. salivarius strains, which could be destined to broilers at farms. Different formulated media based on whey permeate (WP) supplemented with nitrogenous sources were evaluated: yeast extract (YE), whey hydrolysate (WH) and $\mathrm{MnSO}_{4} \cdot \mathrm{H}_{2} \mathrm{O}(\mathrm{Mn})$, $\mathrm{MgSO}_{4} .7 \mathrm{H}_{2} \mathrm{O}(\mathrm{Mg})$. The growth of each strain in the formulated media and the cost was compared with their growth and cost in commercial medium (MRS). L. salivarius DSPV008P did not grow adequately in any of the formulated media. On the other hand, addition of $\mathrm{YE}$ and $\mathrm{Mn}$ in the formulated media increased L. salivarius DSPV002P and L. salivarius DPSV011P growth. In contrast, WH and Mg addition increased the L. salivarius DSPV002P biomass only. L. salivarius DSPV011P was the only strain that had similar growth performance in MRS as in the selected medium: WP + YE 8g/l + Mn. In this sense, L. salivarius DSPV011P reached a biomass of 9.22 $\log (\mathrm{CFU} / \mathrm{ml})$ in the selected formulated medium, with a low-cost growth medium 12 times less than in MRS. Although the effect of supplements added to the culture medium on kinetic parameters are strain dependent, L. salivarius DSPV011P is the strain with the best technological characteristics, capable of growing in a medium based on a by-product of the dairy industry supplemented with YE and $\mathrm{Mn}$ and at a much less cost than in MRS medium.

RESUMEN. Desarrollo de un medio de cultivo de bajo costo para la producción de biomasa potencialmente probiótica destinado a pollos parrilleros. El objetivo de este trabajo fue evaluar diferentes medios de cultivo de bajo costo para la producción de biomasa de 3 cepas potencialmente probióticas de L. salivarius, las cuales podrían ser destinadas a pollos parrilleros en las granjas. Para ello se evaluaron diferentes formulaciones basadas en permeado de suero de queso (WP) suplementado con fuentes nitrogenadas: extracto de levadura ( $\mathrm{YE}$ ) e hidrolizado de suero $(\mathrm{WH})$ y $\mathrm{MnSO}_{4} \cdot \mathrm{H}_{2} \mathrm{O}(\mathrm{Mn}), \mathrm{MgSO}_{4} \cdot 7 \mathrm{H}_{2} \mathrm{O}(\mathrm{Mg})$. El crecimiento de las cepas en estas formulaciones y el costo económico fue comparado con el crecimiento y costo en el medio de cultivo comercial (MRS). L. salivarius DSPV008P no creció adecuadamente en ninguno de los medios evaluados. Por otro lado, la adición del YE y Mg al medio mejoró el desarrollo microbiano de L. salivarius DSPV002P y L. salivarius DPSV011P. El agregado de WH y Mn solo tuvo un efecto positivo en el incremento de la biomasa de L. salivarius DSPV002P. L. salivarius DSPV011P fue la única cepa que desarrolló la misma cantidad de biomasa en MRS y en el medio seleccionado WP + YE $8 \mathrm{~g} / \mathrm{L}+\mathrm{Mn}$. L. salivarius DSPV011P logró un desarrollo de biomasa de $9.22 \mathrm{Log}$ (UFC/ml) en el medio seleccionado con un costo económico 12 veces menor que en MRS. Aunque el efecto de los suplementos añadidos al medio de cultivo sobre los parámetros cinéticos depende de la cepa, L. salivarius DSPV011P es la cepa con mejores características tecnológicas, capaz de crecer en un medio a base de un subproducto de la industria láctea suplementado con YE y Mn y a un costo mucho menor que en MRS.

Keywords: probiotic, Lactobacillus salivarius, whey permeate, biomass production

Palabras clave: probiótico, Lactobacillus salivarius, permeado de suero, producción de biomasa 


\section{Introduction}

In broiler farms, the environment, management measures and nutrition can modify the intestinal microbial conditions and facilitate infection by pathogens (Scallan et al., 2011). Pathogenic microorganisms could cause morbidity and mortality resulting in enormous economic losses in the poultry production (Hossain et al., 2017).

The use of antibiotics in feed intended for poultry to prevent disease is usually a common practice. In this sense, antibiotics are used at sub-therapeutic doses as growth promoters in order to improve production performance (Bedford et al., 2000; Hung et al., 2012). However, the current trend is to avoid the use of antibiotics as growth promoters due to the concern for the emergence of resistant strains. In Argentina, the National Service of Agrifood Health and Quality banned the use of antibiotics as growth promoters since 2019 (SENASA, 2015). Therefore, it is necessary to evaluate alternative tools which provide a solution to this problem. Probiotics emerge as an alternative to antibiotic, they are used to prevent diseases or as growth promoters. Probiotics were defined as live microorganisms that, administered in adequate amounts, confer a beneficial effect on the health of the host (FAO, 2001). Balanced microbiota of gastrointestinal tract can provide efficient protection against pathogenic microorganisms, leading to better animal performance (Hung et al., 2012; Niba et al., 2009).

The viability and quantity of microorganisms at the time of inoculation are of vital importance to produce the probiotic effects. The probiotic exerts their effect if they are viable and at a minimum concentration of $10^{6}$ $\mathrm{CFU} / \mathrm{ml}$ (Vinderola et al., 2000). Therefore, to produce a probiotic inoculum to supplement feed for broilers, the culture medium has to be optimized to obtain a high viable microorganisms yield with low cost raw materials.

Lactic acid bacteria (LAB) have been proposed as and are used as probiotic strains (Blajman et al., 2017). Lactic acid bacteria (LAB) are a nutritionally demanding group of microorganisms. They need a wide range of nutrients to grow and synthesize metabolic products, and some nutritional requirements are usually strain specific (Hammes et al., 2009). LAB are characterized by using different sources of carbon and produce mainly lactic acid as the final product of metabolism. According to the metabolism, LAB are classified as homo- and hetero-fermentative. L. salivarius is obligately homofermentative and has the ability to ferment lactose unlike other LAB species (Wood et al., 1995).

There are commercial growth media formulated specifically for LAB such as MRS (De Man et al., 1960). It contains macro and micronutrients specific to this bacterial group. However, the large-scale production of Lactobacillus spp. in MRS is not profitable, so is interesting evaluate the use of by-products of the industry as low-cost growth medium. The by-products of the dairy industry could be used as alternative culture media to the MRS. In this sense, WP is a lowcost product used as growth medium of probiotic bacteria and it is an alternative input to obtain probiotic biomass in a more economical way (Hugo et al., 2016).

WP is generally composed of lactose (70 - 90\%), protein (0.5 - 3\%) and could have traces of mineral salts such as phosphate, potassium, magnesium, sodium, calcium (Hu et al., 2014; Trigueros et al., 2016). However, with the aim to obtain an optimal microbial growth in WP, is necessary to add different nutrients according to the species or strains of $L A B$ evaluated. In this sense, supplementation with nitrogenous sources and mineral salts is necessary and usually it is a limiting factor for the industrial production of biomass. The cost of supplementing the medium with YE can represent up to $38 \%$ of the final cost of biomass production (Altaf et al., 2007). Its high cost affects the economic efficiency of the production of biomass, so it is important to reduce $Y E$ concentration or find economical alternatives of nitrogenous sources. For this purpose, WH could be used as a low cost additive to increase biomass production (Kwon et al., 2000).

The supplementation of the medium with hydrolyzed proteins has the advantage of providing the bacteria with a more accessible nitrogen source and also, in some cases, with greater bioactivity (Dabrowska et al., 2017). Likewise, positive effect of the addition of salts such as $\mathrm{Mn}$ and $\mathrm{Mg}$ on microbial mass growth of different BAL species has been demonstrated previously (Raccach et al., 1985).

To evaluate the performance of $L A B$, the study of their kinetic parameters of growth are the basic tools to scale the biotechnological processes evaluated in the laboratory. This allows predicting the development of fermentation and evaluating the yields and productivities in the processes (De Man et al., 1960). The most important parameters of microbial growth are: the maximum specific growth rate ( $V$ max), the time it takes the bacteria to reach the maximum growth rate (TVmax), the lag time or Lag phase (Lag) and the maximum number of bacteria reached (Nmax). The knowledge of the behavior of growth kinetic parameters, would allow to diminish the times and to increase the yields of the industrial processes.

Therefore, the aim of this study was to evaluate the growth of potential probiotic $L$. salivarius in low-cost media based on WP, supplemented with nitrogenous sources and mineral salts. This bacteria biomass could be used as feed supplement in broilers farms for diseases prevention and improve the animal growth parameters. 


\section{Materials and methods}

\section{Microorganisms}

The strains from avian origin were: $L$. salivarius DSPV002P, L. salivarius DSPV008P and $L$. salivarius DSPV011P. They belong to LAA ICiVet / UNL-CONICET and were selected for their resistance to gastrointestinal conditions, cell surface hydrophobicity and production of antimicrobial compounds (Blajman et al., 2015). These strains were qualified for further evaluation as potential probiotics. Their GenBank access numbers are KU295171, KU295177 and KU295180, respectively. The strains were maintained in a cryoprotective medium based on tryptone broth with glycerin $(17 \% \mathrm{v} / \mathrm{v})$ and sterile equine serum $(5 \% \mathrm{v} / \mathrm{v})$ at $-80^{\circ} \mathrm{C}$ until use.

\section{Preparation of WH}

WH was obtained using $2 \mathrm{~L}$ batch thermostatic reactor. The enzymatic hydrolysis parameters were selected according to manufacturer's guidelines and previous assays (Soto et al., 2006). A dispersion of $6 \mathrm{~g} / 100 \mathrm{~g}$ whey protein was prepared by dissolution in distilled water. Temperature $(\mathrm{T})$ was brought to $55^{\circ} \mathrm{C}$ in a water bath, during $20 \mathrm{~min}$ under gentle agitation. The reaction $\mathrm{pH}$ was adjusted to 6.0. Enzymatic digestion of substrate was performed at $55^{\circ} \mathrm{C}$, using Flavourzyme at enzyme/ substrate ratio ( $\mathrm{E} / \mathrm{S}$ ) of $5 \mathrm{~g} / 100 \mathrm{~g}$. The $\mathrm{pH}$ was continuously measured using an IQ Scientific Instruments $\mathrm{pH}$-meter and adjusted by addition of 3 $\mathrm{mol} / \mathrm{L} \mathrm{NaOH}$. Hydrolysis was performed for $4 \mathrm{~h}$. Enzyme activity was stopped by heating the dispersion at $85^{\circ} \mathrm{C}$ for $5 \mathrm{~min}$. After inactivation treatment, the solutions were cooled to room temperature with tap water, and refrigerated at $4{ }^{\circ} \mathrm{C}$ until use in the experiments.

Free amino groups were measured using ophtaldialdehide, according to Nielsen et al. (2001), and the degree of hydrolysis $(\mathrm{DH})$ was calculated as:

$$
\mathrm{DH}=\left[\left(\mathrm{h}-\mathrm{h}_{0}\right) / \mathrm{h}_{\text {tot }}\right] \times 100
$$

Where: $h_{\text {tot }}$ : is the total number of peptide bonds in the protein substrate $(8.8 \mathrm{mEq} / \mathrm{g}$ protein); $\mathrm{h}$ : is the number of peptide bonds cleaved during hydrolysis, and $h_{0}$ : is the content of free amino groups in the substrate.

In this hydrolysis conditions, a WH with $6.3 \% \mathrm{DH}$ was obtained.

\section{Formulated culture media}

The WP was obtained from Arla Foods Ingredients S.A. (Córdoba, Argentina) and contained lactose $(85 \% \mathrm{w} / \mathrm{w})$, ashes ( $\mathrm{Na}$ and $\mathrm{Ca} 6 \% \mathrm{w} / \mathrm{w})$, and proteins $(3 \% \mathrm{w} / \mathrm{w})$ as declared by the manufacturer. It was used as a base medium $60 \mathrm{~g} / \mathrm{L}$ to formulate culture media, which were supplemented with YE (Oxoid, Basingstoke, United Kingdom), WH , Mn (Anedra, San Fernando, Argentina), Mg (Merck, Germany). The concentrations evaluated of each supplement were: YE $(0 \mathrm{~g} / \mathrm{L}, 4 \mathrm{~g} / \mathrm{L}$ and $8 \mathrm{~g} / \mathrm{L}), \mathrm{WH}$ $(0 \mathrm{~g} / \mathrm{l}, 7 \mathrm{~g} / \mathrm{L}$ and $14 \mathrm{~g} / \mathrm{L}), \mathrm{Mn}(0 \mathrm{~g} / \mathrm{L}$ and $0.003 \mathrm{~g} / \mathrm{L}), \mathrm{Mg}(0$ $\mathrm{g} / \mathrm{L}$ and $0.02 \mathrm{~g} / \mathrm{L})$. A total of 36 culture media formulations were obtained as a result of all possible combinations of the different supplements and their concentrations.

\section{Analysis of growth kinetic parameters}

Strains were grown in MRS broth (Biokar, France) in two consecutive cultures for $24 \mathrm{~h}$ at $37^{\circ} \mathrm{C}$. Each strain was inoculated at $1 \% \mathrm{v} / \mathrm{v}(2.4 \mu \mathrm{L})$ in sterile 96-well microplates, which previously contained $240 \mu \mathrm{L}$ of the aforementioned media formulations by triplicate. Optical density (OD $=630 \mathrm{~nm}$ ) were measured on the Multi-Mode Microplate Reader, SynergyTM HT Biotek ${ }^{\circledR}$ for $24 \mathrm{~h}$ every $30 \mathrm{~min}$. Incubation was performed for 24 $\mathrm{h}$ at $37^{\circ} \mathrm{C}$. MRS broth was used as control of optimal growth and each formulated medium without inoculum was used as a negative control. The results were analyzed using the Gen 5 software $\left(\right.$ Biotek $^{\circledR}$ ) and the following growth kinetic parameters were analyzed: Vmax, TVmax, Lag phase and Nmax. Selection of the medium formulated for each strain was based on the best results of the kinetics parameters.

\section{Quantification of the growth of the strains in the selected media}

Strains were grown in MRS broth (Biokar, France) in two consecutive cultures for $24 \mathrm{~h}$ at $37^{\circ} \mathrm{C}$ to obtain a stock culture. Five $\mathrm{ml}$ of these stock cultures were inoculated in: a) $50 \mathrm{ml}$ of the medium that showed the best growth kinetic parameter results of each evaluated strain, b) 50 $\mathrm{ml}$ of WP c) $50 \mathrm{ml}$ of MRS broth. Media were incubated for $24 \mathrm{~h}$ at $37{ }^{\circ} \mathrm{C}$ in aerobiosis. After the incubation, serial dilutions were made in Ringer $1 / 4$ solution and counts in MRS agar were carried out to determine the colony forming unit count per milliliter (CFU/mL).

\section{Economic cost of the formulated media}

Economic cost of the selected culture medium, which produced the best kinetic parameters, was evaluated for each strain. The cost to produce $1000 \mathrm{~L}$ of each culture medium was calculated and compared to the cost of the same volume of MRS (Vázquez et al., 2009). The costs of the selected media were calculated by adding the cost of each ingredient and the MRS cost was calculated from a commercial medium.

\section{Growth of L. salivarius DSPV 011P on the selected formulated medium in a lab reactor scale}

Lactobacilus salivarius was cultured in a $5 \mathrm{~L}$ (Sartorius Stedim Biotech, Goettingen, Germany) with $1 \%$ of initial inoculum obtained by two successive incubations during $24 \mathrm{~h}$ at $37^{\circ} \mathrm{C}$ in MRS. Fermentation was done through a batch process during $18 \mathrm{~h}$ at $37^{\circ} \mathrm{C}$ with $60 \mathrm{~g} / \mathrm{l}$ $\mathrm{WP}, 8 \mathrm{~g} / \mathrm{L} \mathrm{YE}$ and $0.003 \mathrm{~g} / \mathrm{L} \mathrm{MnSO}_{4}$ as culture medium. Agitation was set at $120 \mathrm{rpm}$ and $\mathrm{pH}$ was adjusted to 6 . After the incubation, serial dilutions were made in 
Ringer $1 / 4$ solution and counts in MRS agar were carried out to determine the colony forming unit count per milliliter (CFU/mL).

\section{Statistical analysis}

To select the best medium for each strain studied, the best values of Nmax and Vmax were considered. The effect of supplements on Nmax y Vmax was analyzed using a complete factorial experimental design: 3 (YE: 0 $\mathrm{g} / \mathrm{L}, 4 \mathrm{~g} / \mathrm{L}$ and $8 \mathrm{~g} / \mathrm{L}) \times 3$ (WH: $0 \mathrm{~g} / \mathrm{l}, 7 \mathrm{~g} / \mathrm{L}$ and $14 \mathrm{~g} / \mathrm{L}) \times 2$ (Mn: $0 \mathrm{~g} / \mathrm{L}$ and $0.003 \mathrm{~g} / \mathrm{L}) \times 2 \times \mathrm{Mg}(0 \mathrm{~g} / \mathrm{L}$ and $0.02 \mathrm{~g} / \mathrm{L})$ and Duncan test $(P<0.05)$. When two or more media showed similar values of Nmax and Vmax, a second analysis was performed among these media based on the parameters Tvmax and Lag phase by one-way ANOVA and Duncan's test.

Growth parameters of the selected media were compared with growth parameters of MRS and the basal medium (WP) for each strain by one-way ANOVA and Duncan's test. All statistical analysis were performed with the Statgraphics Plus for Windows program. 11.0. (Statgraphics Plus Software $\left.{ }^{\circledR}, 1997\right)$.

All experiments were carried out in triplicates, with the mean values being reported.

\section{Results}

Selection of formulated media based on kinetics parameters

\section{L. salivarius DSPVO02P}

The highest amount of biomass (Nmax) was obtained when $\mathrm{YE}$ and $\mathrm{WH}$ were at $4 \mathrm{~g} / \mathrm{L}$ and $8 \mathrm{~g} / \mathrm{L}(\mathrm{P}<0.001)$, and at $7 \mathrm{~g} / \mathrm{L}$ and $14 \mathrm{~g} / \mathrm{L}(\mathrm{P}<0.001)$, respectively, and $\mathrm{Mn}$ at $0.003 \mathrm{~g} / \mathrm{L}(\mathrm{P}<0.001)$ in the culture medium. In turn, $\mathrm{Mg}$ did not modify $(\mathrm{P}=0.284)$ L. salivarius DSPV002P growth (Table 1).

On the other hand, the growth rate (Vmax) of $L$. salivarius DSPV002P was the highest when YE and WH were at $4 \mathrm{~g} / \mathrm{L}$ and $8 \mathrm{~g} / \mathrm{L}(P<0.001)$, and $7 \mathrm{~g} / \mathrm{L}$ and $14 \mathrm{~g} / \mathrm{L}$ $(P=0.011)$, respectively, and $M g(P=0.037)$ were present in the medium. The presence of $\mathrm{Mn}$ did not influence the growth rate $(P=0.814)$ (Table 1$)$.

Therefore, in order to obtain the greatest amount of biomass at the shortest time, both nitrogen sources must be present. In turn, it must contain $\mathrm{Mn}$ to obtain high Nmax and Mg to obtain high Vmax. Therefore, the 4 selected media were: $\mathrm{WP}+\mathrm{YE} 4 \mathrm{~g} / \mathrm{L}+\mathrm{WH} 7 \mathrm{~g} / \mathrm{L}+\mathrm{Mn}$ $+\mathrm{Mg} ; \mathrm{WP}+\mathrm{YE} 8 \mathrm{~g} / \mathrm{L}+\mathrm{WH} 7 \mathrm{~g} / \mathrm{L}+\mathrm{Mn}+\mathrm{Mg} ; \mathrm{WP}+\mathrm{YE} 8$ $\mathrm{g} / \mathrm{L}+\mathrm{WH} 14 \mathrm{~g} / \mathrm{L}+\mathrm{Mn}+\mathrm{Mg}$ and $\mathrm{WP}+\mathrm{YE} 4 \mathrm{~g} / \mathrm{L}+\mathrm{WH} 14$ $\mathrm{g} / \mathrm{L}+\mathrm{Mn}+\mathrm{Mg}$ (Table 2).

Nmax and Vmax were higher in the 4 selected media than $N \max (P<0.001)$ and $V \max (P<0.001)$ obtained in the medium without supplementation (WP $60 \mathrm{~g} / \mathrm{L}$ ).
Likewise, Vmax of the 4 selected media were the same, but, Nmax were different between them, obtaining the highest amount of biomass in the medium WP $60 \mathrm{~g} / \mathrm{L}+$ YE $4 \mathrm{~g} / \mathrm{L}+\mathrm{WH} 7 \mathrm{~g} / \mathrm{L}+\mathrm{Mg}+\mathrm{Mn}$ (Table 2). The growth curve obtained in this medium had a lower Nmax and Vmax than the curve obtained in MRS, but both had the same TVmax and Lag fase (Table 2).

\section{L. salivarius DSPV008P}

The highest amount of biomass (Nmax) was obtained when $\mathrm{YE}$ and $\mathrm{WH}$ were at $4 \mathrm{~g} / \mathrm{L}$ and $8 \mathrm{~g} / \mathrm{L}(\mathrm{P}<0.001)$, and $7 \mathrm{~g} / \mathrm{L}$ and $14 \mathrm{~g} / \mathrm{L}(\mathrm{P}=0.047)$, respectively, and $\mathrm{Mg}$ was at $0.02 \mathrm{~g} / \mathrm{L}(\mathrm{P}=0.008)$ in the culture medium. In turn, the presence of $\mathrm{Mn}$ produced a negative effect on Nmax $(P<0.001)$, so this supplement should be absent (Table 3).

Supplements that increased the kinetic parameter Vmax were the presence of $\mathrm{YE}$ and $\mathrm{WH}$ at $4 \mathrm{~g} / \mathrm{L}$ y $8 \mathrm{~g} / \mathrm{L}$ $(P<0.001)$ and $7 \mathrm{~g} / \mathrm{L}$ and $14 \mathrm{~g} / \mathrm{L}(P=0.016)$, respectively. $\mathrm{Mg}(\mathrm{P}=0.073)$ and $\mathrm{Mn}(\mathrm{P}=0.785)$ did not produce any effect on Vmax (Table 3). Thus, it follows that the 4 media coincided with the highest levels of Nmax and Vmax were: $W P+Y E 4 g / L+W H 14 \mathrm{~g} / \mathrm{L}+\mathrm{Mg}$; WP + YE 8 $\mathrm{g} / \mathrm{L}+\mathrm{WH} 7 \mathrm{~g} / \mathrm{L}+\mathrm{Mg} ; \mathrm{WP}+\mathrm{YE} 8 \mathrm{~g} / \mathrm{L}+\mathrm{WH} 14 \mathrm{~g} / \mathrm{L}+\mathrm{Mg}$ and $W P+Y E 4 g / L+W H 7 g / L+M g$ (Table 4).

Even though the factors that benefited the growth of $L$. salivarius DSPV008P were determined, the selected media did not allow an adequate growth. The selected media generated an increase in biomass compared to the basal medium WP $60 \mathrm{~g} / \mathrm{L}$, but the growth was well below the growth in MRS. Therefore, none of the selected media was suitable for the development of this strain (Table 4).

\section{L. salivarius DSPV011P}

The highest amount of biomass (Nmax) was obtained when $\mathrm{YE}$ and $\mathrm{Mn}$ were at $4 \mathrm{~g} / \mathrm{L}$ and $8 \mathrm{~g} / \mathrm{L}(P<0.001)$ and $0,003 \mathrm{~g} / \mathrm{L}(P<0.001)$, respectively in the culture medium. On the other hand, $\mathrm{Mg}$ and $\mathrm{WH}$ did not affect the growth of the strain $(P=0.383$ and $P=0.508$, respectively) (Table 5).

Supplement that increased the kinetic parameter Vmax was $Y E$ in its 2 concentrations: $4 \mathrm{~g} / \mathrm{L}$ and $8 \mathrm{~g} / \mathrm{L}(P$ $<0.001)$. Further, $\mathrm{Mg}, \mathrm{Mn}$ and $\mathrm{WH}$ did not affect $\mathrm{Vmax}$ $(\mathrm{P}=0.199, \mathrm{P}=0.638$ and $\mathrm{P}=0.146$, respectively) (Table 5). Therefore, the 2 selected media were: WP $60 \mathrm{~g} / \mathrm{l}+$ YE $4 \mathrm{~g} / \mathrm{I}+\mathrm{Mn}$ and WP $60 \mathrm{~g} / \mathrm{I}+\mathrm{YE} 8 \mathrm{~g} / \mathrm{I}+\mathrm{Mn}$, but the latter was the one that produced the largest amount of biomass at the highest speed (Table 6).

Furthermore, Nmax of the selected medium (WP $60 \mathrm{~g} / \mathrm{l}$ + YE $8 \mathrm{~g} / \mathrm{l}+\mathrm{Mn}$ ) was equal to Nmax in MRS. In the same way, all the other kinetic parameters evaluated were similar in the selected medium and MRS, generating similar growth curves (Table 6 ). 
Tabla 1. Lactobacilus salivarius DSPV002 kinetic parameters for factors: yeast extract, whey hydrolyzate, MgSO4.7H2O and $\mathrm{MnSO} 4 . \mathrm{H} 2 \mathrm{O}$ in its different concentrations. Vmax: the maximum specific growth rate; Nmax: the maximum number of bacteria reached. Different letters mean significant differences $(P<0.05)$ among different concentrations of each factor for each kinetic parameter.

\begin{tabular}{|c|c|c|c|}
\hline \multicolumn{1}{|c|}{ Factors } & Concentration & $\begin{array}{c}\text { Nmax } \\
\text { (Mean } \pm \text { SD) }\end{array}$ & $\begin{array}{c}\text { Vmax } \\
\text { (Mean } \pm \text { SD) }\end{array}$ \\
\hline & $0 \mathrm{~g} / \mathrm{L}$ & $0.30 \pm 0.120^{\mathrm{b}}$ & $1.29 \pm 1.250^{\mathrm{b}}$ \\
\hline \multirow{2}{*}{ Yeast extract } & $4 \mathrm{~g} / \mathrm{L}$ & $0.77 \pm 0.246^{\mathrm{a}}$ & $2.34 \pm 0,829^{\mathrm{a}}$ \\
\cline { 2 - 5 } & $8 \mathrm{~g} / \mathrm{L}$ & $0.83 \pm 0.212^{\mathrm{a}}$ & $2.34 \pm 0.774^{\mathrm{a}}$ \\
\hline $\mathrm{MgSO}_{4} .7 \mathrm{H}_{2} \mathrm{O}$ & 0 & $0.63 \pm 0.317^{\mathrm{a}}$ & $1.86 \pm 1.143^{\mathrm{b}}$ \\
\hline Whey & 0.02 & $0.64 \pm 0.330^{\mathrm{a}}$ & $2.12 \pm 1.022^{\mathrm{a}}$ \\
\hline hydrolyzate & $0 \mathrm{~g} / \mathrm{L}$ & $0.54 \pm 0.307^{\mathrm{b}}$ & $2.25 \pm 1.158^{\mathrm{b}}$ \\
\hline $\mathrm{MnSO}_{4} \cdot \mathrm{H}_{2} \mathrm{O}$ & $7 \mathrm{~g} / \mathrm{L}$ & $0.69 \pm 0.345^{\mathrm{a}}$ & $2.90 \pm 0.995^{\mathrm{a}}$ \\
\hline & $14 \mathrm{~g} / \mathrm{L}$ & $0.68 \pm 0.287^{\mathrm{a}}$ & $2.82 \pm 0.889^{\mathrm{a}}$ \\
\hline & 0 & $0.59 \pm 0.281^{\mathrm{b}}$ & $1.98 \pm 1.107^{\mathrm{a}}$ \\
\hline
\end{tabular}

Tabla 2. Lactobacilus salivarius DSPV002 kinetic parameters for selected media, WP (whey permeate) without supplementation and positive control (MRS). YE: yeast extract; WH: whey hydrolysate; $\mathrm{Mn}$ : MnSO4.H2O; Mg: MgSO4.7H2O; Vmax: the maximum specific growth rate; TVmax: the time it takes the bacteria to reach the maximum growth rate; Fase Lag; the lag time or Lag phase; Nmax: the maximum number of bacteria reached. Different letters mean significant differences $(P<0.05)$ among the selected media.

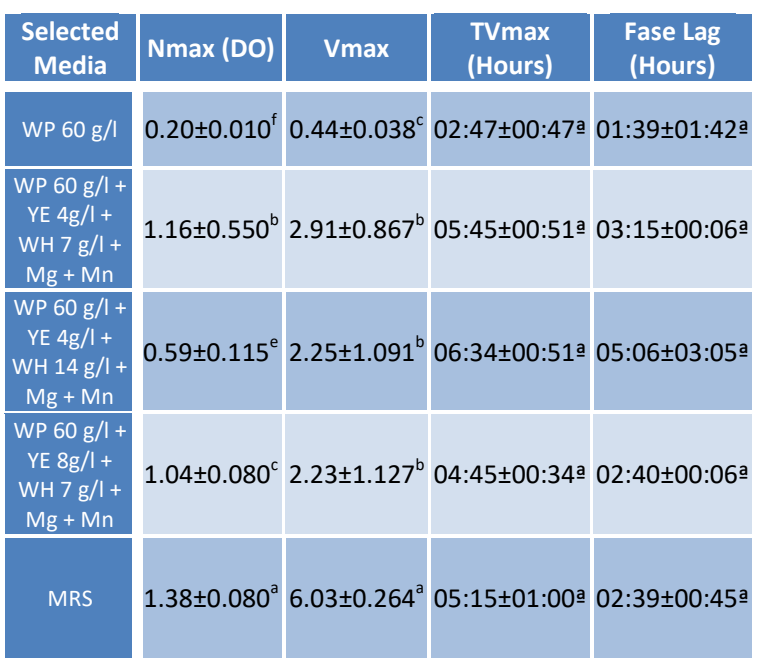

\section{Biomass production and economic cost of selected media}

L. salivarius DSPV002P viable cells count obtained in WP medium was lower $(7.05 \log \mathrm{CFU} / \mathrm{mL})$ than in the selected medium (WP $60 \mathrm{~g} / \mathrm{l}+\mathrm{YE} 4 \mathrm{~g} / \mathrm{l}+\mathrm{WH} 7 \mathrm{~g} / \mathrm{l}+\mathrm{Mg}+$ $\mathrm{Mn}, 8.31 \log \mathrm{CFU} / \mathrm{mL})$. However, growth in the latter medium was lower than in MRS medium (8.68 log $\mathrm{CFU} / \mathrm{mL})(\mathrm{P}<0.001)$. Nevertheless, biomass production cost in MRS (\$USD 120.55/1000L) was 20 times higher than in selected medium (SUSD 5.75/1000L).
Tabla 3. Lactobacilus salivarius DSPV008 kinetic parameters for factors: yeast extract, whey hydrolyzate, MgSO4.7H2O and MnSO4.H2O in its different concentrations. Vmax: the maximum specific growth rate; Nmax: the maximum number of bacteria reached. Different letters mean significant differences $(P<0.05)$ among different concentrations of each factor for each kinetic parameter.

\begin{tabular}{|c|c|c|c|}
\hline \multicolumn{1}{|c}{ Factors } & Concentration & $\begin{array}{c}\text { Nmax } \\
\text { (Mean } \pm \text { SD) }\end{array}$ & $\begin{array}{c}\text { Vmax } \\
\text { (Mean } \pm \text { SD) }\end{array}$ \\
\hline & $0 \mathrm{~g} / \mathrm{L}$ & $0.15 \pm 0.044^{\mathrm{b}}$ & $0.53 \pm 0.309^{\mathrm{b}}$ \\
\hline Yeast extract & $4 \mathrm{~g} / \mathrm{L}$ & $0.18 \pm 0.032^{\mathrm{a}}$ & $0.95 \pm 0.246^{\mathrm{a}}$ \\
\cline { 2 - 4 } & $8 \mathrm{~g} / \mathrm{L}$ & $0.20 \pm 0.023^{\mathrm{a}}$ & $1.12 \pm 0.283^{\mathrm{a}}$ \\
\hline $\mathrm{MgSO}_{4} \cdot 7 \mathrm{H}_{2} \mathrm{O}$ & 0 & $0.17 \pm 0.040^{\mathrm{b}}$ & $0.87 \pm 0.364^{\mathrm{a}}$ \\
\hline Whey & 0.02 & $0.18 \pm 0.049^{\mathrm{a}}$ & $0.86 \pm 0.383^{\mathrm{a}}$ \\
\hline hydrolyzate & $0 \mathrm{~g} / \mathrm{L}$ & $0.17 \pm 0.033^{\mathrm{b}}$ & $0.79 \pm 0.298^{\mathrm{b}}$ \\
\hline $\mathrm{MnSO}_{4} \cdot \mathrm{H}_{2} \mathrm{O}$ & $7 \mathrm{~g} / \mathrm{L}$ & $0.18 \pm 0.048^{\mathrm{a}}$ & $0.86 \pm 0.397^{\mathrm{ab}}$ \\
\hline & $14 \mathrm{~g} / \mathrm{L}$ & $0.18 \pm 0.051^{\mathrm{a}}$ & $0.95 \pm 0.410^{\mathrm{a}}$ \\
\hline & 0 & $0.20 \pm 0.045^{\mathrm{a}}$ & $0.82 \pm 0.345^{\mathrm{a}}$ \\
\hline & 0.003 & $0.16 \pm 0.036^{\mathrm{b}}$ & $0.91 \pm 0.404^{\mathrm{a}}$ \\
\hline
\end{tabular}

Tabla 4. Lactobacilus salivarius DSPV008 kinetic parameters for selected media, WP (whey permeate) without supplementation and positive control (MRS). YE: yeast extract; WH: whey hydrolysate; $\mathrm{Mn}$ : MnSO4.H2O; Mg: MgSO4.7H2O; Vmax: the maximum specific growth rate; TVmax: the time it takes the bacteria to reach the maximum growth rate; Fase Lag; the lag time or Lag phase; Nmax: the maximum number of bacteria reached. Different letters mean significant differences $(P<0.05)$ among the selected media.

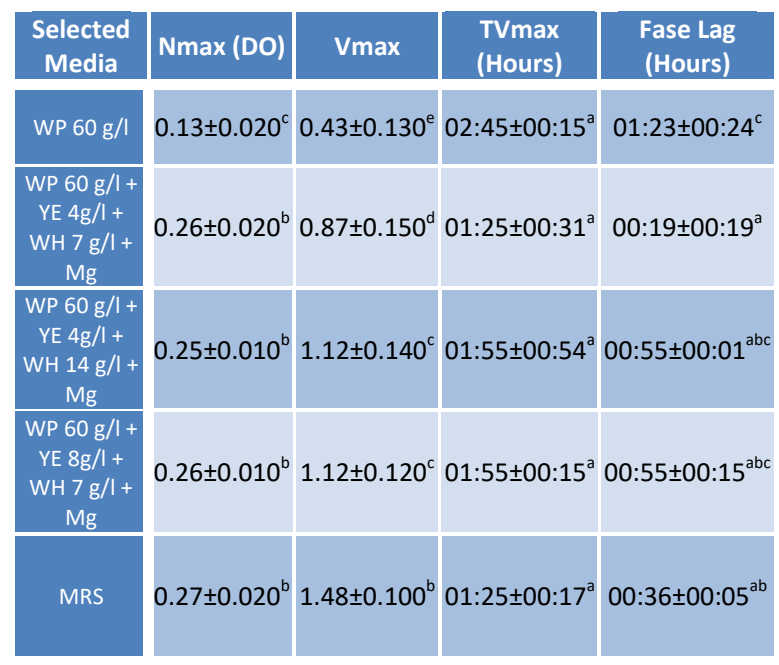

On the other hand, L. salivarius DSPV011P biomass obtained in WP medium was lower (7.05 log CFU/mL) than biomass obtained in the selected medium (WP + YE $8 \mathrm{~g} / \mathrm{L}+\mathrm{Mn}$, $8.93 \mathrm{log} \mathrm{CFU} / \mathrm{mL}$ ) and in MRS (8.95 log $\mathrm{CFU} / \mathrm{mL})(\mathrm{P}<0.001)$. Further, production costs of $L$. salivarius DSPV011P biomass would be 12 times less in the selected media (\$USD 9.88/1000L) than in MRS (\$USD 120.55/1000L).

Since L. salivarius DSPV 011P was the only strain capable of generating an Nmax equal to MRS, biomass production in the selected medium was further evaluated in a laboratory scale bioreactor. Under these 
conditions, the biomass production was $9.22 \mathrm{log}$ (CFU/mL), increasing $0.29 \log (\mathrm{CFU} / \mathrm{mL})$ more than in the test tube.

L. salivarius DSPV 008P viable cell count analysis was not performed because this strain did not grow adequately in any of the formulated media.

Tabla 5. Lactobacilus salivarius DSPV011 kinetic parameters for factors: yeast extract, whey hydrolyzate, MgSO4.7H2O and $\mathrm{MnSO}$.H2O in its different concentrations. Vmax: the maximum specific growth rate; Nmax: the maximum number of bacteria reached. Different letters mean significant differences $(P<0.05)$ among different concentrations of each factor for each kinetic parameter.

\begin{tabular}{|l|c|c|c|}
\hline \multicolumn{1}{|c|}{ Factors } & Concentration & $\begin{array}{c}\text { Nmax } \\
\text { (Mean } \pm \text { SD) }\end{array}$ & $\begin{array}{c}\text { Vmax } \\
\text { (Mean } \pm \text { SD) }\end{array}$ \\
\hline Yeast extract & $0 \mathrm{~g} / \mathrm{L}$ & $0.27 \pm 0.139^{\mathrm{b}}$ & $0.87 \pm 0.567^{\mathrm{b}}$ \\
\cline { 2 - 5 } & $4 \mathrm{~g} / \mathrm{L}$ & $0.90 \pm 0.171^{\mathrm{a}}$ & $2.39 \pm 0.958^{\mathrm{a}}$ \\
\hline $\mathrm{MgSO}_{4} .7 \mathrm{H}_{2} \mathrm{O}$ & $8 \mathrm{~g} / \mathrm{L}$ & $0.87 \pm 0.177^{\mathrm{a}}$ & $3.09 \pm 1.219^{\mathrm{a}}$ \\
\hline Whey & 0 & $0.68 \pm 0.354^{\mathrm{a}}$ & $2.167 \pm 1.306^{\mathrm{a}}$ \\
\hline hydrolyzate & 0.02 & $0.69 \pm 0.297^{\mathrm{a}}$ & $2.064 \pm 1.337^{\mathrm{a}}$ \\
\hline & $0 \mathrm{~g} / \mathrm{L}$ & $0.68 \pm 0.421^{\mathrm{a}}$ & $2.20 \pm 1.145^{\mathrm{a}}$ \\
\hline $\mathrm{MnSO}_{4} \cdot \mathrm{H}_{2} \mathrm{O}$ & $7 \mathrm{~g} / \mathrm{L}$ & $0.65 \pm 0.285^{\mathrm{a}}$ & $1.93 \pm 1.278^{\mathrm{a}}$ \\
\hline & $14 \mathrm{~g} / \mathrm{L}$ & $0.73 \pm 0.252^{\mathrm{a}}$ & $2.22 \pm 1.259^{\mathrm{a}}$ \\
\hline & 0 & $0.64 \pm 0.093^{\mathrm{b}}$ & $2.15 \pm 1.266^{\mathrm{a}}$ \\
\hline
\end{tabular}

Tabla 6. Lactobacilus salivarius DSPV011 kinetic parameters for selected media, WP (whey permeate) without supplementation and positive control (MRS). YE: yeast extract; WH: whey hydrolysate; Mn: MnSO4.H2O; Mg: MgSO4.7H2O; Vmax: the maximum specific growth rate; TVmax: the time it takes the bacteria to reach the maximum growth rate; Fase Lag; the lag time or Lag phase; Nmax: the maximum number of bacteria reached. Different letters mean significant differences $(P<0.05)$ among the selected media.

\begin{tabular}{|c|c|c|c|c|}
\hline $\begin{array}{l}\text { Selected } \\
\text { Media }\end{array}$ & $N \max (D O)$ & Vmax & $\begin{array}{l}\text { TVmax } \\
\text { (Hours) }\end{array}$ & $\begin{array}{l}\text { Fase Lag } \\
\text { (Hours) }\end{array}$ \\
\hline WP $60 \mathrm{~g} / \mathrm{l}$ & $0.22 \pm 0.062^{c}$ & $0.50 \pm 0.033^{c}$ & $02: 15 \pm 00: 34^{a}$ & $01: 06 \pm 00: 49^{a}$ \\
\hline $\begin{array}{l}\text { WP } 60 \mathrm{~g} / \mathrm{l} \\
+\mathrm{YE} 4 \mathrm{~g} / \mathrm{l} \\
+\mathrm{Mn}\end{array}$ & $1.05 \pm 0.152^{b}$ & $3.23 \pm 0.333^{b}$ & $03: 34 \pm 00: 17^{a}$ & $01: 21 \pm 00: 14^{a}$ \\
\hline $\begin{array}{l}\text { WP } 60 \mathrm{~g} / \mathrm{l} \\
+\mathrm{YE} 8 \mathrm{~g} / \mathrm{l} \\
+\mathrm{Mn}\end{array}$ & $1.29 \pm 0.132^{a}$ & $4.46 \pm 0.121^{\mathrm{a}}$ & $02: 34 \pm 00: 17^{a}$ & $00: 52 \pm 00: 13^{a}$ \\
\hline MRS & $1.34 \pm 0.132^{a}$ & $4.78 \pm 0.184^{a}$ & $03: 55 \pm 00: 21^{a}$ & $01: 36 \pm 00: 14^{a}$ \\
\hline
\end{tabular}

\section{Discussion}

For the formulation of an industrial-culture medium is necessary that it has all the nutritional requirements to support an appropriate microorganism growth. These additives have to be abundant in the market and of low production cost (León de la $\mathrm{O}$ et al., 2013; Vázquez et al., 2009). In this study, different formulations of culture media were evaluated taking into account the kinetic characteristics of growth of three strains of $L$. salivarius from avian origin, which manifested different nutritional requirements, different growth times and reached different final counts.

The applied statistical methodology was very useful to identify the factors effects on the biomass production and with these data the most appropriate medium was made. These media produced different results according to the strain: an optimal growth was obtained for L. salivarius DSPV011P; a high growth was obtained for L. salivarius DSPV002P, but not as high as that obtained in MRS medium; and low growth was obtained for L. salivarius DSPV008P. Different studies have reported that the inclusion of YE or protein lysate, magnesium sulfate, manganese sulfate and vitamins improve the production of lactic acid in cheese whey used as growth media (Cui et al., 2012; Kwon et al., 2000; Vázquez et al., 2009). Likewise, differences in the nutritional requirements of microorganisms can promote or suppress the definitive genetic properties of Lactobacillus spp. through epigenetic reprogramming (Shenderov, 2014). In addition, there is a high heterogeneity in the metabolic properties among species and bacterial strains (Mikelsaar et al., 2015). However, most $L A B$ require an exogenous nitrogen source of amino acids or peptides to support cell growth (Manca de Nadra, 2007).

Among all the factors evaluated, the addition of YE to the base medium (WP) improved the growth of two of the three strains under study. Microorganisms with complex nutritional requirements may need small amounts of essential nutrients. Such nutrients, called growth factors (Amrane y Prigent, 1998), include purines and pyrimidines (necessary for the synthesis of nucleic acids), amino acids (necessary for the synthesis of proteins) and vitamins (necessary as coenzymes and functional groups of certain enzymes). Growth factors are not directly metabolized as carbon or energy sources; rather they are assimilated by the cells to fulfill their specific role in the metabolism (Manca de Nadra, 2007). The use of YE is advantageous over other possible nitrogenous sources, since it also provides vitamins and bases of nucleic acids essential for the production of purified proteins (Amrane y Prigent, 1998).

It has been described that some probiotic strains improve the yield of biomass production when hydrolysates are added to the formulated medium (Dabrowska et al., 2017; Kareba et al., 2018). Nonetheless, growth kinetics may vary with the presence and/ or concentration of WH depending on the strain. Each strain can have different peptide transport systems which can carry free amino acids, diand tri-peptides and oligopeptides of up to six amino acid residues. Therefore, the growth capacity will depend on the degree of hydrolysis achieved in the WH and the pathway for the transport of amino acids of each strain (Dabrowska et al., 2017). In this study, WH 


\section{DSPV002P.}

The strains also differed in the use of mineral salts for the development of their biomass. The mineral salts used in this work, $\mathrm{Mn}$ and $\mathrm{Mg}$, are of utmost importance for cell growth since they function as essential co-factors for the enzymes in the primary metabolism of LAB sugars (Madigan et al., 2004). In addition, both metal ions play a central role in the production of NAD and ATP and, therefore, are essential for many cellular functions (Vinderola et al., 2000). Such is the case of $L$. salivarius DSPV002P, since it required the addition of both salts minerals. However, L. salivarius DSPV011P had its highest yields in the presence of $\mathrm{Mn}$ and without the addition of $\mathrm{Mg}$. This may be due these two divalent metal ions have very similar chemical properties and $\mathrm{Mg}$ ions can be exchanged for $\mathrm{Mn}$ ions at the metal binding sites of many proteins (Lew et al., 2012). However, the Mn requirement has a certain degree of specificity and it cannot be completely replaced by other metals (Raccach, 1985).

Studying the kinetic parameters of the growth of microorganisms allows to optimize and standardize the fermentation process both at the laboratory level and at the industrial scale (Kareba et al., 2018; Zapata et al., 2005). In this sense, although the value of Nmax is considered the most important at the level of biomass yield, the other parameters play an important role in the overall evaluation of the process. It is known that the lag phase is the time in which a culture passes from the adaptation phase (Lag) to the logarithmic growth phase (Log) in any kinetic growth study (León de la $\mathrm{O}$ et al., 2013). If this can be shortened by optimizing the culture medium, it will allow the inoculated strain to dominate the fermentation process, preventing possible biological contaminants. In this way, it can be inferred that this microorganism could adapt better to the supplemented medium than to the commercial medium, which implies an advantage for the large-scale fermentation technological process, reducing costs. The maximum growth rate was lower in the medium formulated for $L$. salivarius DSPV002P and $L$. salivarius DSPV008P than the commercial medium, but there was no difference for the case of $L$. salivarius DSPV011P. However, it is known that the specific rate of growth can improve when the growth media are optimized as was described by Zacharof et al. (2009), who reported increases of up to $300 \%$ in the different strains studied. Previous studies have shown that other mineral salts like $\mathrm{K}_{2} \mathrm{HPO}_{2}, \mathrm{NaAc}$ and $\left(\mathrm{NH}_{4}\right)_{2} \mathrm{SO}_{4}$ or different concentrations of the salts evaluated (Cui et al., 2012; Macedo et al., 2002; Trigueros et al., 2016) could optimize the biomass of the strains, because the addition of micronutrients can enhance their role in cell growth.

In relation to the biomass obtained, the results showed that only the strain L. salivarius DSVP011P grew in the
J commercial

medium. In the case of the evaluation of the costs of all the formulations, they turned out to be significantly cheaper than the commercial medium. In particular, the medium formulated for $L$. salivarius DSVP011P cost approximately 12 times less than the commercial medium. As mentioned above, the use of low-cost growth media to obtain probiotic biomass is of great interest at an industrial level to reduce costs and extend its incorporation to feed (León de la $\mathrm{O}$ et al., 2013; Vázquez et al., 2009). In this sense, by-products such cheese whey permeate constitute an alternative for the production of probiotic bacteria (Lavari et al., 2015) destined to slaughter animals.

Although the effect of supplements added to the culture medium on kinetic parameters are strain dependent, L. salivarius DSPV011P is the strain with the best technological characteristics, capable of growing in a medium based on a by-product of the dairy industry supplemented with $\mathrm{YE}$ and $\mathrm{Mn}$ and at a cost 12 times lower than in MRS. However, future studies must be carried out to determine that the physiological properties of this strain are not modified by growth in this formulated medium. The development of a lowcost culture medium for the generation of potential probiotic biomass, would make possible the transfer of L. salivarius DSPV011P and the medium developed for its production on an industrial scale for its application in broilers farms.

\section{References}

Aguirre-Ezlcauriatza EJ, Aguilar-Yañes JM, Ramirez Medrano A, Alvarez MM. 2010. Producción of probiotic biomass (Lactobacillus casei) in goat milk whey: comparion of batch, continuous and fed-batch culture. Bioresour. Technol. 101: 2837-2844.

Altaf M, Naveena BJ, Gopal R. 2007. Use of inexpensive nitrogen sources and starch for $\mathrm{L}(+)$ lactic acid production in anaerobic submerged fermentation. Bioresour. Technol. 93: 498-503.

Amrane A, Prigent Y. 1998. Influence of yeast extract concentration on batch cultures of Lactobacillus helveticus: growth and production coupling. World J. Microb. Biot. 14: 529-534.

Bedford M. 2000. Removal of antibiotic growth promoters from poultry diets: implications and strategies to minimise subsequent problems. World Poultry Sci. J. 56: 347-365.

Blajman J, Gaziano C, Zbrun MV, Soto L, Astesana D, Berisvil A, Scharpen AR, Signorini M, Frizzo L. 2015. In vitro and in vivo screening of native lactic acid bacteria towards their selection as probiotic in broilers. Res. Vet. Sci. 101: 50-6.

Blajman JE, Olivero CA, Fusari ML, Zimmermann JA, Rossler E, Berisvil AP, Romero Scharpen A, Astesana D, Soto LP, Signorini ML, Zbrun, MV, Frizzo LS. 2017. Impact of lyophilized Lactobacillus salivarius DSPV 001P administration on growth performance, microbial translocation, and gastrointestinal 
microbiota of broilers reared under low ambient temperature. Res. Vet. Sci. 114: 388-394.

Cui F, Wan C, Li Y, Liu Z, Rajashekara G. 2012. Co-production of lactic acid and Lactobacillus rhamnosus cells from whey permeate with nutrient supplements. Food Bioprocess. Tech. 5: $1278-1286$

Dąbrowska A, Babij K, Szołtysik M, Chrzanowska J. 2017. Viability and growth promotion of starter and probiotic bacteria in yogurt supplemented with whey protein hydrolysate during refrigerated storage. Postep. Hig. Med. Dosw. 71: 952-959.

De Man, J.C., Rogosa, M., Sharpe, M.E. 1960. A medium for the cultivation of lactobacilli. J. Appl. Bacteriol. 23: 130-135.

Duarte, A. 1998. Introducción a la Ingeniería Bioquímica. Ed. Universidad Nacional de Colombia: Bogotá. 198pp.

FAO WHO. 2001. Evaluation of health and nutritional properties of probiotics in food, including powder milk with live lactic acid bacteria. Food and Agricultural Organization of United Nations and World Health Organization Expert Consultation Report. London, Ontario, Canadá.

Hammes WP, Hertel C. Genus I. Lactobacillus. In de Vos P., Garrity GM, Jones D, Krieg NR, Ludwig W, Rainey FA, Schleifer $\mathrm{KH}$, Whitman WB. (Eds.). 2009. Bergey's manual of systematic bacteriology (2nd ed.) 3: 465-511.

Hossain MI, Sadekuzzaman M, Ha SD. 2017. Probiotics as potential alternative biocontrol agents in the agriculture and food industries: A review. Food Res. Int. 100: 63-73.

Hu Y, Dun Y, Li S, Zhao S, Peng N, Liang Y. 2014. Effects of Bacillus subtilis $\mathrm{KN}-42$ on growth performance, diarrhea and faecal bacterial flora of weaned piglets. Asian-Australas. J Anim. Sci. 27: 1131-40.

Hugo AA, Bruno F, Golowczyc MA. 2016. Whey permeate containing galacto-oligosaccharides as a medium for biomass production and spray drying of Lactobacillus plantarum CIDCA 83114. LWT - Food Sci. Technol. 69: 185-190.

Hung AT, Lin SY, Yang TY, Chou CK, Liu HC, Lu JJ, Wang B, Chen SY. 2012. Effects of Bacillus coagulans ATCC 7050 on growth performance, intestinal morphology, and microflora composition in broiler chickens. Anim. Prod. Sci. 52: 874-879.

Kareba O, Champagnea CP, Jeana J, Gomaa A, Aidera M. 2018. Effect of electro-activated sweet whey on growth of Bifidobacterium, Lactobacillus, and Streptococcus strains under model growth conditions. Food Res. Int. 103: 316-325.

Kwon S, Lee PC, Lee EG, Chang YK, Chang N. 2000 Production of lactic acid by Lactobacillus rhamnosus with vitamin-supplemented soybean hydrolizate. Enzym. Microb. Technol. 26: 209-215

Lavari L, lanniello R, Páez R, Zotta T, Cuatrin A, Reinheimer J, Parente E, Vinderola G. 2015. Growth of Lactobacillus rhamnosus 64 in whey permeate and study of the effect of mild stresses on survival to spray drying. LWT - Food Sci. Technol. 63: 322-330.

Lazzi C, Meli F, Lambertini F, Bottesini C, Nikolaev I, Gatti M, Sforza S, Koroleva O, Popov V, Neviani E, Dossena A. 2013.
Growth promotion of Bifidobacterium and Lactobacillus species by proteinaceous hydrolysates derived from poultry processing leftovers. Int. J. Food Sci. Technol. 48: 341-9.

León-de la O DI, Calderón-Yépez B, Martínez-Ballinas I, Sánchez-Herrera E.M, Zulatto-Lobato AC, Camacho-Hernández I, Arredondo-Villanueva AL, Salgado-Brito R. 2013. Formulation and optimization of an economic broth culture for Lactobacillus with probiotic potential isolated from pulque. Investigación Universitaria Multidisciplinaria: Revista de Investigación de la Universidad Simón Bolívar 12: 133-144.

Lew LC, Gan CY, Liong MT. 2012. Growth optimization of Lactobacillus rhamnosus FTDC 8313 and the production of putative dermal bioactives in the presence of manganese and magnesium ions. J. Appl. Microbiol. 114: 526-535.

Liao SF, Nyachoti M. 2017. Using probiotics to improve swine health and nutrient utilization. Anim. Nutr. 3: 331-343.

Macedo MG, Lacroix C, Gardner NJ, Champagne CP. 2002. Effect of medium supplementation on exopolysaccharide production by Lactobacillus rhamnosus RW-9595M in whey permeate. Int. Dairy J. 5: 419-426.

Manca de Nadra MC. 2007. Nitrogen metabolism in lactic acid bacteria from fruits: A review. En: A. Méndez-Vilas, editor. Communicating current research and educational topics and trends in applied microbiology. Formatex. Pp. 500-510.

Madigan MT, Martinko JM, Parker J. 2004. Biología de los microorganismos. $10^{a}$ ed. Prentice Hall. Madrid, España. 991 pp.

Mikelsaar M, Sepp E, Štšepetova J, Hütt P, Zilmer K, Kullisaar T, Zilmer M. 2015. Regulation of plasma lipid profile by Lactobacillus fermentum (probiotic strain ME-3 DSM14241) in a randomised controlled trial of clinically healthy adults. BMC Nutr. 1: 1-27.

Niba AT, Beal JD, Kudi AC, Brooks PH. 2009. Bacterial fermentation in the gastrointestinal tract of non-ruminants: influence of fermented feeds and fermentable carbohydrates. Trop. Anim. Health Pro. 41: 1393-1407.

Nielsen PM, Petersen D, Dambmann, C. 2001. Improved method for determining food protein degree of hydrolysis. J. Food Sci. 66: 642-646.

Raccach M. 1985. Manganese and lactic acid bacteria. J. Food Protect. 48: 895-898.

Remely M, Aumueller E, Jahn D, Hippe B, Brath H, Haslberger AG. 2014. Microbiota and epigenetic regulation of inflammatory mediators in type 2 diabetes and obesity. Benef. Microbes 5: 33-43.

Scallan E, Hoekstra RM, Angulo FJ, Tauxe RV, Widdowson MA, Roy SL, Jones JL, Griffin PM. 2011. Foodborne illness acquired in the United States-major pathogens. Emerg. Infect. Dis. 17: 7-15.

SENASA. Resolución 294/2015. 2015. http://www.senasa.gov.ar/senasa-comunica/noticias/nuevaspautas-tecnicas-para-la-elaboracion-de-productos destinadosla-alimentación-de-animales. 
Soto LP, Drago SR, Frizzo LS, Diaz A, Gonzalez R, Rosmini MR. 2006. Efecto de hidrolizados proteicos sobre el crecimiento de Lactobacillus casei DSPV 318T. II Simposio Internacional de Bacterias Lácticas. Primer encuentro Red BAL Argentina, San Miguel de Tucumán, Argentina.

Trigueros DEG, Fiorese ML, Kroumov AD, Hinterholz CL, Nadai BL, Assuncao GM. 2016. Medium optimization and kinetics modeling for the fermentation ofhydrolyzed cheese whey permeate as a substrate for Saccharomycescerevisiae var. boulardii. Biochem. Eng. J. 110:71-83.

Vázquez S, Crosa MJ, Rey F, Lopretti M. 2009. Viabilidad de uso de suero de quesería como base del medio de cultivo de la cepa nativa probiótica Lactobacillus paracasei HA9-2. INNOTEC 4: 10-4.

Vinderola CG, Bailo N, Reinheimer JA. 2000. Survival of probiotic microflora in Argentinian yoghurts during refrigerated storage. Food Res. Int. 33: 97-102.

Weymarn N, Hujanen M, Leisola M. 2002. Production of Dmannitol by heterofermentative lactic acid bacteria. Process. Biochem. 37:1207-13.

Wood BJB, Holzapfel WH. 1995. The genera of lactic acid bacteria. ${ }^{\text {st }}$ Edition. Blackie Academic \& professional. 398 pp.

Zacharof MP, Lovitt RW, Ratanapongleka K. 2009. Optimization of Growth Conditions for Intensive Propagation, Growth Development and Lactic Acid Production of Selected Strains of 'Lactobacilli'. In: Engineering Our Future: Are We up to the Challenge?: 27 - 30 September 2009, Burswood Entertainment Complex. Barton, ACT: Engineers Australia

Zapata JE, Hoyos M, Quinchía LA. 2005. Kinetic parameters of growth of Saccharomyces cerevisiae affected by a varying magnetic field of low intensity and high frequency. Vitae 12: 39-44. 